Artikel Penelitian

\title{
PENGARUH OVARIEKTOMI TERHADAP KADAR VEGF,TGF- $\beta$, IGF, DAN CA15-3 PADA PASIEN KANKER PAYUDARA STADIUM LANJUT USIA MUDA
}

\author{
Rini Suswita ${ }^{1}$, Wirsma Arif ${ }^{1}$, Edison $^{2}$, Zelly Diarofinda $^{3}$
}

\begin{abstract}
Abstrak
Kanker payudara stadium lanjut pada usia muda dikaitkan dengan gambaran klinis, patologis dan prognosis yang lebih buruk dibanding usia tua. Ovariektomi merupakan terapi paliatif yang efektif pada pasien ini, dengan menurunkan kadar estradiol yang akan mempengaruhi gen yang terlibat dalam proses proliferasi, diferensiasi, metastasis, angiogenesis, invasi, dan apoptosis. Penelitian ini bertujuan untuk mengetahui pengaruh ovariektomi terhadap kadar VEGF, TGF $\beta$, IGF dan CA15-3 pada pasien kanker payudara stadium lanjut usia muda. Penelitian ini menggunakan desain pre dan post test pada 12 pasien kanker payudara stadium lanjut usia muda sebagai subyek penelitian. Pemeriksaan kadar VEGF, TGF $\beta$, IGF dan CA 15-3 dilakukan sebelum dan tiga bulan sesudah pasien dilakukan tindakan ovariektomi dengan menggunakan teknik ELISA, kemudian dilakukan analisis statistik dengan uji non parametrik. Penelitian menemukan peningkatan kadar VEGF, TGF $\beta$, IGF dan CA 15-3 dan menurun sesudah dilakukan ovariektomi. Analisis statistik menunjukkan pengaruh ovariektomi yang bermakna terhadap penurunan kadar VEGF $(p=0,023)$, TGF $\beta(p=0,02)$, dan CA 15-3 ( $p=0,002)$, tetapi tidak berpengaruh terhadap kadar IGF( $p=875)$. Ovariektomi dapat menurunkan kadar VEGF, TGF $\beta$ dan CA 15-3 serum, sehingga dapat dipertimbangkan sebagai terapi pilihan pada kanker payudara stadium lanjut usia muda.
\end{abstract}

Kata Kunci : ovariektomi, usia muda, kanker payudara, stadium lanjut

\begin{abstract}
Advanced breast cancer in young age is associated with worse clinical features, pathology and prognosis than old age. Oophorectomy may be an effective palliative therapy in these patients, by decreasing estradiol concentration which will affect genes involved in proliferation, differentiation, metastasis, angiogenesis, invasion, and apoptosis. This research aimed at examining the effect of oophorectomy on the levels of VEGF, TGF- $\beta$, IGF and CA15-3 in patients with advanced breast cancer in young age. This study used a pre and post test design in twelve patients with advanced breast cancer in young age. The level of VEGF, TGF- $\beta$, IGF and CA 15-3 was measured before and three months after oophorectomy using the ELISA technique. Data was analyzed with non-parametric test. Of the twelve patients studied, there were increased levels of VEGF, TGF- $\beta$, IGF, and CA 15-3 before oophorectomy and there was a decrease after oophorectomy performed. Statistical analysis showed that oophorectomy significantly decreased levels of VEGF $(p=0,023)$, TGF- $\beta(p=0,02)$, and CA 15-3 $(p=0,002)$, but no significant effect on the decrease in IGF levels $(p=0,875)$. Oophorectomy reduces levels of VEGF, TGF $\beta$ and CA 15-3 serum significantly in the first three months of observation. Thus, it could be considered for the management of advanced breast cancer in young age.
\end{abstract}

Keyword : ovariectomy, young women, advanced stage, breast cancer

Afiliasi Penulis: 1. Bagian IImu Bedah Fakultas Kedokteran Universitas Andalas /RSUP. Dr.M.Djamil, Padang, 2. Bagian IImu Kesehatan Masyarakat Fakultas Kedokteran Universitas Andalas, 3. Bagian Patologi Klinik Fakultas Kedokteran Universitas Andalas/RSUP.Dr.M.Djamil. Korespondensi: dr. Rini Suswita, Bagian IImu Bedah Fakultas Kedokteran Universitas Andalas /RSUP. Dr.M.Djamil, Padang,Jl. Peritnis Kemerdekaan No. 94, PO BOX 49 Padang 25127, Email: ristarini@gmail.com. 


\section{PENDAHULUAN}

Kanker payudara merupakan masalah global, sering didapatkan pada wanita di negara maju. Kanker ini termasuk peringkat kedua setelah kanker servik yang dilaporkan di negara berkembang. Insiden kanker payudara semakin meningkat, saat ini lebih dari 170.000 kasus ditemukan pertahun. Insiden kanker payudara bervariasi di tiap negara, tertinggi ditemukan di Swedia dengan rata-rata insiden 129,5/100.000 wanita dan terendah di Jepang 37/100.000 wanita. Menurut national cancer institute's surveillance, epidemiology and result program, insidens kanker payudara meningkat cepat selama dekade IV kehidupan. ${ }^{1-2}$

Kanker payudara di Indonesia menurut WHO 2008 merupakan jenis kanker yang tersering. Kasus ini ditemukan sebanyak 39.831 kasus baru dengan angka kejadian $36,2 / 100.000$ wanita. Data dari laporan rumah sakit di Indonesia (2009), menunjukkan bahwa kanker payudara merupakan penyebab terbanyak kematian karena kanker pada wanita. Sampai saat ini belum ada data yang pasti berapa jumlah kanker payudara di Indonesia. Angka kunjungan di RS Dr.M.Djamil Padang, penderita kanker payudara pada tahun 2012 tercatat sebanyak 73 orang dengan perincian berdasarkan stadium yaitu stadium I 6 $\%$, stadium II $18 \%$, stadium III 44\% dan stadium IV 36\%. ${ }^{1-2}$

Sebagian besar penderita kanker payudara datang ke rumah sakit pada stadium lanjut dengan rerata usia sekitar 47 tahun dan status pra- menopause. Usia merupakan faktor prognostik penting dalam penanganan pasien kanker payudara, terutama untuk usia di bawah 40 tahun. Angka kunjungan pasien kanker payudara usia muda di RSUP Dr.M Djamil padang tahun 2012 sebanyak 17\%.

Usia muda umumnya dikaitkan dengan gambaran klinis, patologis dan prognosis yang lebih buruk jika dibandingkan usia tua. Oleh karena itu, usia muda ini sering dihubungkan dengan status pra-menopause dengan kadar hormon estrogen dan progesteron yang tinggi. Hormon-hormon ini sebagian besar diproduksi oleh ovarium dan hanya sebagian kecil saja yang diproduksi di luar ovarium. Hormon steroid ini diperlukan dalam pertumbuhan normal kelenjar payudara maupun dalam proses patologis. 2-5

Penatalaksanaan kanker payudara stadium lanjut pada prinsipnya hanya bersifat paliatif karena sel kanker sudah mengalami penyebaran jauh, baik secara mikroskopis atau radiologis. Penatalaksanaan kasus ini, tindakan lokal seperti bedah dan radioterapi tidak berperan dalam meningkatkan survival pasien. Terapi pilihan untuk stadium ini adalah kemoterapi ataupun terapi hormonal. Pengobatan kanker payudara telah mengalami evolusi panjang, bahkan pemberian kemoterapi berdasarkan parameter klinis dan morfologi mulai ditinggalkan. Ada kecendrungan pada era genomic ini pemeriksaan genomic micro arrray dianggap lebih mampu memisahkan kelompok yang cocok kemoterapi dengan yang tidak perlu 
mendapatkan kemoterapi atau cukup terapi hormonal saja. ${ }^{6-11}$

Tindakan ovariektomi dapat dijadikan terapi manipulasi hormonal tertua pada kanker payudara untuk menurunkan kadar hormon estrogen dan progesteron. Pertama kali dilakukan oleh Beatson GT pada tahun 1896. Tindakan ini sudah lazim dilakukan selama lebih 1 abad. Banyak penelitian menunjukkan bahwa penurunan estrogen dan progesteron dengan cara ovariektomi pada penderita kanker payudara pramenopause dapat mempengaruhi perjalanan penyakitnya sehingga mendapatkan angka survival yang baik. Penurunan estrogen dan progesteron akibat ovariektomi akan memengaruhi perjalanan penyakit disebabkan aktivitas estradiol yang akan mempengaruhi 700 gen secara langsung dan 1300 gen ikutan. Estradiol mempengaruhi gen yang terlibat dalam proses proliferasi, diferensiasi, metastasis, angiogenesis, invasi, dan apoptosis. ${ }^{12-14}$

Keadaan fisiologi normal, angiogenesis dikontrol melalui keseimbangan antara pro-angigenesis dan anti-angiogenesis dalam jaringan. Jalur angiogenesis ada beberapa parameter yang mengaktivasi dan menghambat pertumbuhan kanker payudara, salah satu faktor parameter dalam angiogenesis tersebut adalah vascular endothelial growth factor (VEGF). Aktivitas ligan VEGF yang berperan pada proses angiogenesis ini dapat diamati pada jaringan dan darah dihubungkan dengan microvessel density (MVD) dan laju amplifikasi messenger RNA (mRNA VEGF). ${ }^{15-20}$
Estrogen dan progesteron yang dihasilkan oleh ovarium merupakan modulator yang kuat bagi pembentukan VEGF dan reseptornya selain keadaan hipoksia. ${ }^{15-20}$ Parameter dalam angiogenesis lainnya adalah transforming growth factor-beta (TGF$\beta)$. Penelitian yang dilakukan pada tikus, ditemukan bahwa ovariektomi dapat menurunkan kadar mRNA dari TGF. ${ }^{21-24}$

Insulin-like growth factors (IGFs) adalah mitogen yang penting dalam meregulasi proliferasi sel, diferensiasi sel dan apoptosis dan memblok sel penghambat pertumbuhan kanker. Ovariektomi menurunkan konsentrasi TGF- $\beta$ dalam tulang tikus, namun tidak mengubah konsentrasi IGF. Namun belum ada dilakukan percobaan mengenai pengaruh ovariektomi terhadap level dari faktor-faktor angiogenesis seperti TGF- $\beta$ dan IGF. ${ }^{25-27}$

Cancer Antigen 15-3 (CA15-3) yang juga dikenal sebagai MUC1 adalah produk dari gen mucin 1 yang merupakan glikoprotein transmembran dari keluarga mucin. MUC1 diekspresikan pada permukaan sel epitel sekretori termasuk kelenjar payudara, traktus gastrointestinal, respiratorius, urinarius dan reproduksi. Fungsi MUC1 adalah untuk proteksi dan lubrikasi permukaan epitel serta terlibat dalam interaksi antar sel, sinyal sel dan metastasis. CA15-3 diekspresikan berlebihan pada beberapa adenokarsinoma dalam bentuk underglycosylated dan masuk ke dalam sirkulasi. Peningkatan CA15-3 bersamaan dengan alkali fosfatase 
dihubungkan dengan peningkatan rekurensi kanker payudara. ${ }^{28-33}$

Perbedaan kadar VEGF, TGF$\beta$, IGF, dan CA15-3 pada penderita kanker payudara yang diterapi dengan ovariektomi dapat dijadikan parameter efektifitas tindakan pada pasien. Efektifitas ini dapat menekan biaya pengobatan bagi pasien. Penelitian ini belum pernah dilakukan sebelumnya. Oleh karena itu, perlu kiranya dilakukan penelitian mengenai pengaruh ovariektomi terhadap kadar VEGF, TGF $\beta$, IGF dan CA15-3 pada pasien kanker payudara stadium lanjut usia muda.

\section{METODE}

Jenis penelitian ini adalah eksperimental dengan desain pre dan post test. Target penelitian ini adalah pasien kanker payudara usia muda stadium lanjut yang berobat ke RS M.Djamil Padang dan RS Ibnu Sina dari Juni 2013-September 2014. Jumlah sampel yang didapatkan dalam penelitian ini sebanyak 12 orang.

Penderita Kanker payudara berusia usia pre-menopausal (di bawah 40 tahun) dan tidak memiliki keluarga dekat (saudara perempuan kandung atau ibu kandung) yang menderita kanker payudara. Penderita kanker payudara yang hamil/ menyusui, tidak diikutkan dalam penelitian ini. Periksaan kadar VEGF, TGF $\beta$, IGF dan CA 15-3 serum sebelum dan tiga bulan sesudah dilakukan ovariektomi, dengan menggunakan teknik ELISA. Analisis statistik dilakukan dengan menggunakan uji non parametrik (uji wilcoxon) dan diolah data secara komputerisasi.

\section{HASIL DAN PEMBAHASAN}

Pengaruh ovariektomi terhadap kadar VEGF, TGF- $\beta$, IGF dan CA15-3 pada penderita kanker payudara stadium lanjut usia muda dapat dilihat pada tabel 1.

Tabel 1 memperlihatkan bahwa Kadar VEGF rata-rata sebelum ovariektomi 464,58 pg/ml dan sesudah ovariektomi 295,26 pg/ml. Perbedaan kadar VEGF sebelum dan sesudah ovariektomi secara statistik bermakna dimana $\mathrm{p}<0,05$.

Kadar TGF $\beta$ rata-rata sebelum ovariektomi didapat $38,53 \mathrm{pg} / \mathrm{ml}$ dan sesudah ovariektomi 23,97 $\mathrm{pg} / \mathrm{ml}$. Hasil pemeriksaan kadar TGF $\beta$ sebelum dan sesudah ovariektomi terdapat perbedaan bermakna secara statistik yaitu $p<0,05$. Begitu juga dengan kadar CA15-3 sebelum dan sesudah ovariektomi terdapat perbedaan yang bermakna. Namun berbeda dengan kadar IGF dimana sebelum ovariektomi didapatkan sebanyak $141.70 \mathrm{pg} / \mathrm{ml}$, sedangkan sesudah ovariektomi 129,42 $\mathrm{pg} / \mathrm{ml}$, secara statistik tidak terdapat perbedaan yang signifikan $p=0,875$. 


\section{Tabel 1. Pengaruh Ovariektomi Terhadap Kadar VEGF, TGF $\beta$, IGF dan CA15-3 Serum Sebelum dan Sesudah Ovariektomi}

\begin{tabular}{ccc}
\hline \multicolumn{1}{c}{ Kadar Serum } & $\begin{array}{c}\text { Median } \\
\text { (Minimal-Maksimal) }\end{array}$ & P \\
\hline VEGF(pg/ml) & $464,58(111,74-1263,43)$ & $\mathrm{P}=0,023$ \\
$\quad$ Sebelum Ovariektomi & $295,26(90-1222,11)$ & \\
Sesudah Ovariektomi & & \\
TGF $\beta$ (pg/ml) & $38,53(9,54-56,69)$ & $\mathrm{P}=0,02$ \\
Sebelum Ovariektomi & $23,97(2,72-35,90)$ & \\
Sesudah Ovariektomi & & $\mathrm{P}=0,875$ \\
IGF(ng/ml) & $141.70(52,68-304,82)$ & \\
Sebelum Ovariektomi & $129,42(41,72-332,22)$ & \\
Sesudah Ovariektomi & & $\mathrm{P}=0,002$ \\
CA15-3 (U/ml) & $34,36(24,72-37,38)$ & \\
Sebelum Ovariektomi & $24,63(24,05-28,89)$ & \\
Sesudah Ovariektomi & & \\
\hline
\end{tabular}

Vascular endothelial growth factor adalah glikoprotein pro-angiogenik yang berfungsi meningkatkan proliferasi, migrasi, dan survival pada sel endotel serta meningkatkan permeabilitas kapiler. Vascular endhotelial growth factor adalah sinyal kunci yang digunakan oleh sel yang kekurangan oksigen (oxygen hungry cell) untuk memicu pertumbuhan pembuluh darah.

Penelitian ini dilakukan pada kanker payudara stadium lanjut usia muda. Semua pasien pada penelitian ini menunjukkan peningkatan kadar VEGF sebelum dilakukan ovariektomi. Beberapa penelitian sudah dilakukan untuk mengevaluasi kadar VEGF serum dengan diagnosis pertumbuhan tumor, metastasis, kekambuhan, survival, dan prognosis jelek pada kanker payudara. Beberapa penelitian membuktikan peningkatan kadar VEGF serum seiring dengan stadium dan faktor prognosis. Kadar VEGF serum pada pasien kanker payudara stadium IV meningkat signifikan bila dibandingkan dengan kanker payudara derajat I, II, and III. ${ }^{34-38}$

Kadar VEGF serum dapat digunakan sebagai petanda prognosis untuk menentukan rekurensi dan metastasis kanker payudara, tetapi tidak banyak berperan pada tahap awal penyakit sehingga tidak mempunyai peran dalam skrining penyakit. Kadar VEGF serum berkorelasi kuat dengan derajat III, ukuran tumor $>2$ $\mathrm{cm}$, limfonodi (+), status reseptor hormon dan invasi vaskuler. ${ }^{36-39}$

Peningkatan kadar VEGF ini dianggap merupakan hasil dari sekresi sel-sel kanker, tumor infiltrating inflammatory cell, dan tumor 
associated stroma ke dalam sirkulasi. Bertindak pada sel endotel untuk mempromosikan angiogenesis. Ini juga merupakan hasil dari hipoksia dan hypoxia inducible factor pada kanker payudara yang memainkan peran penting dalam peningkatan kadar VEGF serum. Selain itu, VEGF mungkin bertanggungjawab untuk penurunan imunitas tubuh pada kanker stadium lanjut, melalui pengurangan maturasi sel-sel dendrit yang penting sebagai antigen presenting cells. Untuk alasan ini, kontak yang terlalu lama sel immun terhadap kadar VEGF yang tinggi dapat menurunkan respon immun dan kemudian memfasilitasi pertumbuhan tumor. ${ }^{40-43}$

Secara teoritis penilaian respon pemberian terapi dapat dinilai dari kadar VEGF. Penelitian ini didapatkan penurunan kadar VEGF yang bermakna setelah tiga bulan dilakukan ovariektomi. Penurunan kadar VEGF setelah dilakukan ovariektomi, salah satunya disebabkan karena ovarium merupakan penghasil VEGF selain keadaan hipoksia pada jaringan tumor. Dengan kata lain melakukan ovariektomi merupakan strategi yang bisa mendapatkan keuntungan sebagai terapi pada kanker payudara stadium lanjut usia muda. ${ }^{44-48}$

Penelitian ini mendapatkan kadar TGF $\beta$ serum meningkat pada semua pasien $(>6,5 \mathrm{pg} / \mathrm{ml})$. Hal ini sejalan dengan beberapa penelitian, dimana didapatkan peningkatan kadar TGF $\beta$ pada kanker payudara stadium lanjut. Peningkatan ini terjadi karena TGF $\beta$ dihasilkan oleh sel-sel stroma dan sel-sel yang berprolierasi pada kanker payudara. ${ }^{21-23}$
Secara teoritis penilaian respon pemberian terapi juga dapat dinilai dari kadar TGF $\beta$, pada penelitian ini didapatkan penurunan kadar TGF $\beta$ yang bermakna setelah tiga bulan ovariektomi. Pengaruh ovariektomi terhadap kadar TGF $\beta$ masih terbatas penelitiannya pada manusia, tetapi penelitian yang dilakukan pada tikus, ditemukan hasil yang sama dengan hasil penelitian ini dimana terjadi penurunaan kadar mRNA dari TGF- $\beta$ setelah ovariektomi. Penurunan kadar TGF $\beta$ juga pada tulang tikus pasca ovariektomi. $^{21-24 .}$

Penurunan kadar TGF $\beta$ ini kemungkinan disebabkan oleh penurunan produksinya oleh sel-sel stroma; Hal ini merupakan efek dari penurunan proliferasi yang terjadi pasca ovariektomi, sehingga TGF $\beta$ yang di lepaskan ke sirkulasi juga berkurang. TGF $\beta$ terlibat dalam penonaktifan monosit, menghambat aktivasi sel-T dan menekan proliferasi serta differensiasi sel B. Oleh karena itu, dapat disimpulkan bahwa peningkatan kadar TGF $\beta$ membantu sel-sel tumor supaya tidak dikenali oleh sistem imun tubuh. ${ }^{21-23}$

Peningkatan kadar TGF $\beta$, juga menyebabkan peningkatan respon toksis pada jaringan normal yang mendapatkan kemoterapi/ radioterapi. Dengan demikian interaksi antara tumor dan host akan berkurang, baik dalam hal respon terapi maupun penurunan respon immunitas terhadap sel tumor dalam tubuh. Ini berarti bahwa berkurangnya TGF $\beta$ dalam sirkulasi pada pasien kanker payudara dapat mengurangi efek toksik dan meningkatkan imunitas. ${ }^{21-24}$. 
Penelitian ini menunjukkan bahwa kadar TGF $\beta$ menurun setelah dilakukan ovariektomi. Oleh karena itu, ovariektomi bisa dijadikan terapi tunggal untuk meningkatkan imunitas tubuh atau bagian dari multimodalitas terapi dalam mengurangi efek toksik terhadap kemoterapi/radioterapi.

Insulin like growth factors adalah mitogen yang poten untuk proliferasi sel kanker dan sekarang dianggap bahwa peningkatan kadar IGF merupakan faktor resiko untuk kanker payudara pada premenopause. Karena itu secara teoritis penurunan IGF dapat memberikan keuntungan pada individu yang memiliki faktor resiko terkena kanker payudara. ${ }^{25-27}$

Penelitian ini mendapatkan kadar IGF lebih dari normal (>100pg/ml) pada kanker payudara stadium lanjut. Beberapa peneliti juga mendapatkan peningkatan kadar IGF pada kanker payudara. Secara teoritis penilaian respon pemberian terapi dapat dinilai dari kadar IGF. Penelitian ini mendapatkan penurunan kadar IGF tiga bulan sesudah dilakukan ovariektomi dan secara statistik penurunan ini tidak bermakna.

Penelitian tentang peran IGF dalam karsinogenesis telah berkembang setelah ditemukannya kadar IGF serum yang berhubungan dengan pembentukan sel epitel kanker. Selain itu, IGF merupakan hormon sistemik yang ampuh sebagai anti-apoptosis dan mitogenik yang mungkin dapat mempengaruhi perilaku proliferasi sel payudara. ${ }^{25-27}$ Penurunan kadar IGF serum setelah dilakukan ovariektomi pada penelitian ini, kemungkinan disebabkan karena penilaiannya hanya dilakukan jangka pendek, oleh karena itu diperlukan penelitian lain untuk menilai respon secara bertahap.

Penelitian ini didapatkan kadar CA 15-3 yang tinggi. Beberapa peneliti juga mendapatkan peningkatan kadar CA15-3 serum pada kanker payudara, terutama stadium III dan IV. American society of clinical oncology (ASCO) juga menyebutkan bahwa kadar serum CA15-3 meningkat sekitar 50-60\% pada stadium lanjut dan metastasis. Petanda tumor CA 15-3 mempunyai sensitivitas dan spesifitas yang rendah pada tahap awal penyakit dan akan meningkat sejalan dengan semakin lanjut perjalanan penyakit. Berbagai penelitian menemukan peningkatan kadar CA 15-3 pada kanker payudara stadium I hanya sekitar $10 \%$ pasien, stadium II sekitar $20 \%$ pasien, stadium III sekitar $40 \%$ pasien, dan $75 \%$ pasien pada stadium IV. Peningkatan kadar CA15-3 ini disebabkan overekspresi pada permukaan sel epitel kanker payudara dan masuk ke dalam sirkulasi. ${ }^{28,29,33}$.

Penelitian ini mendapatkan penurunan kadar CA 15-3 tiga bulan pasca ovariektomi. Penurunan kadar CA 15-3 merupakan indikasi keberhasilan terapi. Penelitian yang sama juga menilai kadar CA 15-3 sebelum dan sesudah kemoterapi pada kanker payudara stadium lanjut dan menyimpulkan bahwa peningkatan kadar CA 15-3 merupakan prediktif terhadap respon yang buruk terhadap kemoterapi. Penelitian lain juga mendapatkan bahwa kemoterapi CAF, dimana CA 15-3 diperiksa sebelum dan sesudah dilakukan kemoterapi 
pertama dan kedua, namun tidak terdapat penurunan bermakna setelah dilakukan kemoterapi I, tetapi terdapat penurunan bermakna rerata kadar CA 15-3 setelah dilakukan kemoterapi II. ${ }^{28-}$ 30

Penelitian ini juga didapatkan penurunan CA 15-3 yang merupakan faktor prediksi respon positif terhadap terapi yang diberikan. Hal ini juga didukung beberapa peneliti yang menyatakan bahwa beberapa petanda tumor kadarnya berkorelasi dengan keberhasilan pengobatan dan respon terapi. Petanda tumor biasanya meningkat seiring dengan progresivitas penyakit, menurun pada penyakit yang mengalami remisi dan tidak ada perubahan yang signifikan pada keadaan yang stabil. Kadar petanda tumor yang menurun secara konsisten merupakan indikasi keberhasilan terapi, sehingga dapat disimpulkan ovariektomi merupakan terapi pilihan pada kanker payudara stadium lanjut usia muda. ${ }^{28,29,31,32 .}$

\section{Angka Harapan Hidup}

Berdasarkan American cancer society, surveillance and health services research, didapatkan angka harapan hidup pada kanker stadium lanjut sesuai dengan terapi yang diberikan adalah sebagai berikut: Breast conserving surgery $2 \%$, breast conserving surgery + radioterapi $1 \%$, dan breast conserving surgery + radioterapi + kemoterapi 10\%. Angka harapan hidup untuk mastektomi adalah 7\%, mastektomi ditambah kemoterapi (14\%), namun mastektomi + radioterapi (4\%), dan mastektomi + radioterapi + kemoterapi (34\%). Jika radioterapi dan atau kemoterapi angka harapan hidupnya sekitar $16 \%$ tanpa mastektomi, sedangkan radioterapi atau kemoterapi sekitar $10 \%$ angka harapan hidupnya.

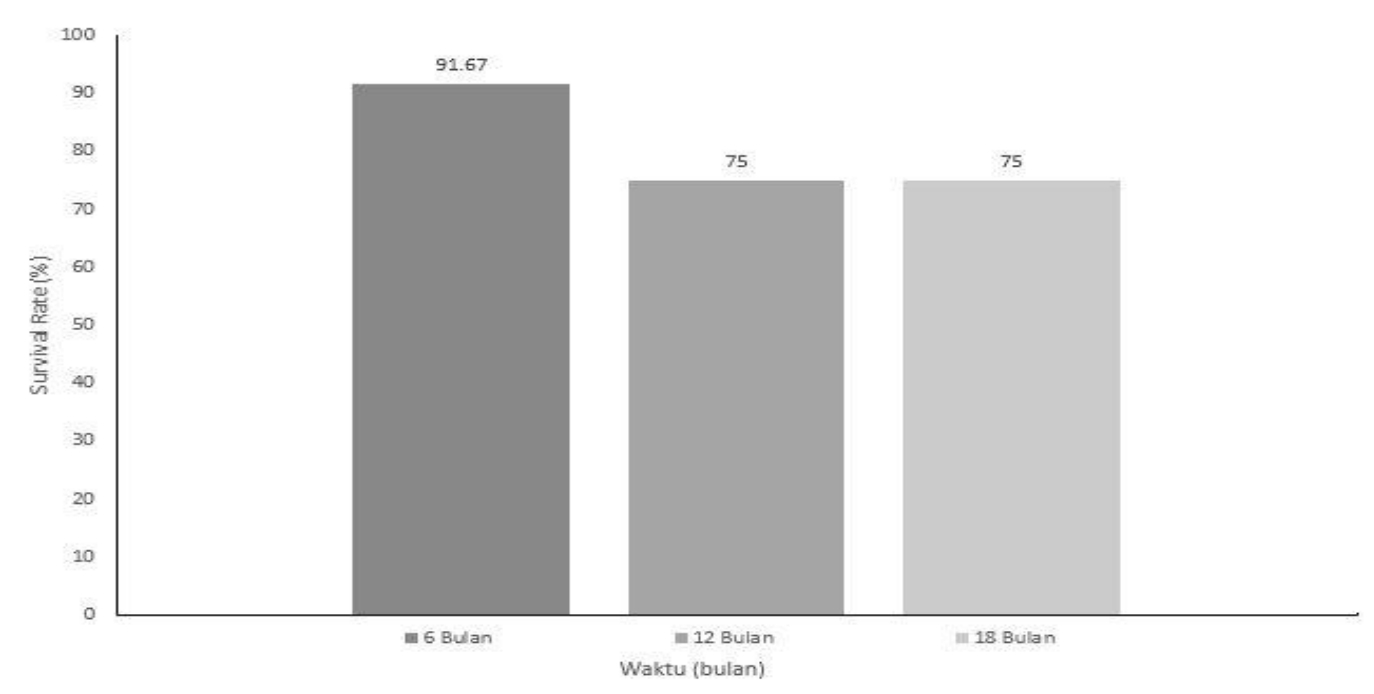

Gambar 1. Angka Harapan Hidup pada Kanker Payudara Stadium Lanjut Usia Muda 
Data tentang angka ketahanan hidup pada pasien payudara stadium lanjut yang dilakukan ovariektomi belum dipublikasikan dan dapat dilihat pada gambar1. Dimana pada gambar 1 menunjukan angka harapan hidup 6 bulan 91,67\%, angka harapan hidup 12 bulan $75 \%$, dan angka harapan hidup 18 bulan $75 \%$. Penelitian ini hanya menilai angka harapan hidup dalam jangka pendek, diperlukan penelitian lain untuk menilai respon secara bertahap sehingga bermanfaat untuk penilaian prognosis dan kualitas hidup pasien.

\section{SIMPULAN}

Penelitian ini dapat disimpulkan bahwa terdapat pengaruh ovariektomi yang bermakna terhadap penurunan kadar VEGF, TGF $\beta$, dan CA 15-3 serum, namun tidak berpengaruh terhadap penurunan kadar IGF.

\section{DAFTAR RUJUKAN}

1. Breast cancer survival rates by stage. Available from: www.cancer.org. 2013.

2. Ramli $M$, Tjindarbumi $D$, Watanabe $S$, Darwis I, Sakamoto G, Cornain S, et al. Clinicopathological aspects of breast cancer: a joint study betwen Indonesia and Japan. Med J Indonesia 1995;4:148-53.

3. Jemal A. Ward E. Michael J Tun. Recent trends in breast cancer incidence rates by age and tumor characteristic among US women. Breast Cancer Res 2007;9(3):R28.

4. Aryandono T. Faktor prognosis kanker payudara operable di
Yogyakarta. Tesis Fakultas Kedokteran Universitas Gadjah Mada 2006.

5. Anders CK, Johnson R, Litton J, Philips M, Bleyer A. Breast cancer before age 40 years. Semin Oncol 2009;36(3)2337-249.

6. Harris JR, Lippman ME, Morrow M, Osborn CK. In: William L and Wilkins, editors. Disease of the breast. $3^{\text {th }}$ ed. Philadelvia 2004.

7. Saclaider TJ, Milikan KW, Godelas $\mathrm{CV}$, editors. Surgical oncology an algorithmic aproach. Springer-Verlag. Newyork 2003.

8. Bourdeaue $V$, Deschenes J, Laperriere D, Aid M. Mechanism of primary and secondary estrogen target gene regulation in breast cancer. Nucleic Acids Res 2008; 36(1):76-93.

9. Edward JF. Jeffrey A. Quinn A. Frackelton AR. Bland KI, Estrogen Action Via G Protein-coupled receptor, GPR30: stimulation adenyl cyclase and $\mathrm{C}$ AMP-mediated attenuation of the epidermal growth factor receptor to MAPK signaling axis. Mol Endocrinolog 2002; 16(1): 70-84.

10. Thomas P, Pang Y, Filardo J, Dong J. Identity of an estrogen membrane receptor coupled to a $G$ protein in human breast cancer cells. Endocrinolog 2005;146(2):624-32.

11. Cavaliere E, Frenkel K, Liehr JG, Rogan E, Roy D. Estrogens and progesterons as endogenous agentsDNA adducts and mutations. J Natl Cancer Inst Monogr 2000;27: 75.

12. Ingle JN, Krook JE, Green SJ, Kubista TP, Everson LK, Ahmann DL et al. Randomized trial of bilateral oophorectomy versus tamoxifen in premenopausal women with metastatic breast cancer. J Clin Oncol 1986;4(2):178-185. 
13. Buchanan RB, Blamey RW, Durrant KR, Howell A, Paterson AG, Preece $P E$ et al. A randomized comparison of tamoxifen with surgical oophorectomy in premenopausal patients with advanced breast cancer. J Clin Oncol 1986;4(9):1326-30.

14. Veronique B, Deschenes J, Laperriere D, Aid $M$, White JH, Mader S. Mechanism of primary and secondary estrogen target gene regulation in breast cancer. Nuclear Acids Res 2008;36(1):76-93.

15. Hyder SM. Review. sex - steroid regulation of vasculer endothelial growth factor in breast cancer. Endocrinolog Related Cancer 2006; 13:66-687.

16. Badrosin C. Positive correlation betwen estradiol and vasculer endothelial growth factor but not fibroblst growth factor 2 in human normal breast tissue in vivo. Clin Cancer Res 2005;11(22).8036-41.

17. Hyder SM, Nawaz Z, Chiappetta C, Stancel GM. Identification of functional estrogen response elements in the gene coding for the potent angiogenic factor vascular endothelial growth factor. Cancer Res 2000;60:3183-90.

18. Filho AL, Lopes JM, Schmit FC. Angiogenesis and breast cancer. J Oncolog 2010:1-7.

19. Elkin $M$, Orgel $A$, and Kleinman HK . An angiogenis switch in breast cancer involves estrogen and soluble vasculer endothelial growth factor receptor 1. J Nation Cancer Ins 2004;96:875-78.

20. Folkman J. Angiogenesis and breast cancer. J Clin Oncol 1994;12:441-43.

21. Roberts AB, Anzano MA, Wakefield LM, Roche NS, Stern DF, Sporn MB. Type- $\beta$ transforming growth factor: a bifunctional regulator of cellular growth. Proc Natl Acad Sci U S A 1985;82:119-23.

22. Tang B, Vu M, Booker T, Santner SJ, Miller FR, Anver MR et al. Clin. Invest 2003;112:1116-24.

23. Elliott RL, Blobe GC. Role of transforming growth factor beta in human cancer. J Clin Onco 2005;23: 2078-88.

24. Jurnal Nature Cell Biology. Sinyal Genetik TGF- $\beta$. Diakses dari: www.kesimpulan.com.2009/10/sinyalgenetik-tgf-beta-telusuri.html.

25. Cory S, Vaux DL, Strasser A, Harris AW, Adams JM. Insights from Bcl-2 and Myc: malignancy involves abrogation of apoptosis as well as sustained proliferation. Cancer Res 1999;59(7suppl):1685-92.

26. Herbert Yu, Thomas Rohan. Role of the insulin-like growth factor family in cancer development and progression. J Natl Cancer Inst 2000;92(18):147289.

27. Lee AV, Jackson JG, Gooch JL, Hilsenbeck SG, Coronado-Heinsohn E, Osborne CK, Yee D. Enhancement of insulin-like growth factor signaling in human breast cancer: estrogen regulation of insulin receptor substrate-1 expression in vitro and in vivo. Mol Endocrinol 1999;13:787-96.

28. Norum LF, Nilsson O, Nustad K. Automated immunofluorometric assay for MUC. Tumor Biol 2001; 22:169-75.

29. Sandri MT, Salvatici M, Botteri E, et al. Prognostic role of CA 15.3 in 7942 patients with operable breast cancer. Br Cancer Res Treat 2012; 132:31726.

30. Gendler SJ. MUC1, the renaissance molecule. J Mammary Gland Biol Neo 2001;21:339-53.

31. Sandri MT, Salvatici M, Botteri $E$, Passerini R, Zorzino L, Rotmensz N, Luini $A$, et al. Ptognostic role of $C A$ 15.3 in 7942 patients with operable 
breast cancer. Breast Cancer Res Treat 2012;132:317-26.

32. Manuali E, De Giuseppe A, Feliziani F, Forti K, Casciari C, Marchesi MC, et al. Ca 15-3 cell lines and tissue expression in canine mammary cancer and the correlation between serum levels and tumour histological grade. BMC Vet Res 2012;8:86.

33. Keshaviah A, Dellapasqua $S$, Rotmensz N, Lindtner J, Crivellari D, Collins J, et al. CA 15-3 and alkaline phosphatase as predictors for breast cancer recurrence: a combined analysis of seven International Breast Cancer Study Group Trials. Ann Oncol 2007;18(4):701-8.

34. Suyatno, Pasaribu. Bedah onkologi diagnostik dan terapi. 2010:35-81.

35. Dahlan Sopiyuddin, membuat proposal penelitian bidang kesehatan. Seri Evidence Based Medicine. Sagung Seto:79-96.

36. Khafagy W, Salah A, Zalata K. Association of serum vascular endothelial growth factor level with estrogen receptor status in breast cancer patient. Egypt J Surg 2005; 24(4):188-194.

37. Wu Y, Saldana L, Chillar R, Vadgama JV. Plasma vascular endothelial growth factor is useful in assessing progression of breast cancer post surgery and during adjuvant treatment. Int J Oncol 2002; 20(3):509-16.

38. Hoeben $A$, Landuyt $B$, Higley $M$, Wildiers $\mathrm{H}$, Van Oosterom TA, Bruijn E. Vascular endothelial growth factor and angiogenesis. Pharmacol Rev 2004;56:549-80.

39. Ali EM, Sheta M, Abed EM. Elevated serum and tissue VEGF associated with poor outcome in breast cancer patients. Alexandria J Med 2011;47: 217-24.
40. Byrne GJ, McDowell G, Agarawal R, Sinha G, Kumar S, Bundred NJ. Serum vascular endothelial growth factor in breast cancer. Anticancer Res 2007;27(5B):3481-7.

41. Stathopoulos J, Armakolas A, Stathopoulos GP, Gomato IP. Plasma VEGF in breast cancer patients with and without metastases. Onco Letters 2012;201 (1):739-41.

42. Hodorowicz D, Kibil W, Malek A, Szpor, Kulig J, Szefto K. Evaluation Of serum concentrations of vascular endothelial growth factor (VEGF) in breast cancer patients. Pol J Pathol 2012;63:255-60.

43. Hagogoan E. Nilai prediktif serum vascular endothelial growth factor-C (VEGF-C) dan hubungan dengan invasi limfo vaskular pada kanker payudara stadium dini. 2010. Diundu tanggal 25 Agustus 2013. Diakses dari:http://mru.fk.ui.ac.id/index.php?u Page $=$ data.detail\&smod=research\&sp ublic\&idpenelitian $=5246$.

44. Adams J, Carder PJ, Downey S, Sarhan $\mathrm{OH}$, Elbaradey T. Vascular endothelial growth factor (VEGF) in breast cancer:comparison of plasma, serum, and tissue VEGF and microvessel density and effects of tamoxifen. Cancer Res 2000;60:898905.

45. Kamal KH, John R, 2001. Serum vascular endothelial growth factor in breast cancer : its relation with cancer type and estrogen receptor status. Clin Cancer Res 2001;7: 3491-4.

46. Benoy I, Salgado R, Colpaert C, Weytjens R, Vermeulen PB, Dirix LY. Serum interleukin 6, plasma VEGF, serum VEGF and VEGF platelet load in breast cancer patients. Clin Breast Cancer 2002;2(4):311-15.

47. Zhao J, Feng Y, Huangxian J, Jinhai $\mathrm{T}$, Jianwei $\mathrm{Q}$. Correlation between serum vascular endothelial growth 
factor and endostatin levels in patients with breast cancer. Cancer Letters 2004;204:87-95.

48. Ahmed LA, El-Mougy HMT, Sarhan
OHM, Elbaradey T. Diagnostic Value of Serum Vascular Endothelium Factor in Cancer Breast. J Am Sci 2012;8(12):69-74. 